\title{
Pengaruh Lama Waktu Pengasapan Dan Waktu Penyimpanan Terhadap Kandungan Gizi Ikan Tandipan (Dussumieria SP)
}

\author{
Daniel H. Ndahawali ${ }^{1}$ \\ Politeknik Kelautan dan Perikanan Bitung \\ e-mail: ndahawalidaniel@gmail.com \\ Hetty M.P.Ondang ${ }^{2}$ \\ Politeknik Kelautan dan Perikanan Bitung \\ Nova Tumanduk ${ }^{3}$ \\ Politeknik Kelautan dan Perikanan Bitung \\ Fidel Ticoalu ${ }^{4}$ \\ Politeknik Kelautan dan Perikanan Bitung \\ Dyah Ayu Rakhmayeni ${ }^{1}$ \\ Politeknik Kelautan dan Perikanan Bitung
}

\begin{abstract}
ABSTRAK
Pemanfaatan sumberdaya ikan di Indonesia khususnya ikan hasil tangkapan laut baik secara tradisional, semi tradisional, dan modern sudah berkembang dengan baik. Pengolahan ikan tradisional dengan metode pengasapan atau pengeringan cukup berkembang di Indonesia, khususnya di daerah provinsi Sulawesi Utara. Salah satu produk ikan asap kering yang cukup terkenal di Sulawesi Utara khususnya di Kabupaten Minahasa Selatan yakni ikan tandipang. Tujuan dari penelitian ini adalah mengukur kandungan gizi ikan tandipang dan mengukur lama masa simpan ikan tandipang. Mutu adalah gabungan dari sejumlah atribut yang dimiliki oleh bahan atau produk pangan yang dapat dinilai secara organoleptik. Nilai organoleptik ikan asap menurut SNI No. 01-2725-1992 adalah > 7 dengan kriteria kenampakan menarik dan bersih, bau asap cukup tanpa ada tambahan mengganggu, rasa enak, konsistensi padat, kompak serta kering antar jaringan (Nastiti, 2006). Metode penelitian yang digunakan adalah Rancangan Acak Kelompok dengan variabel lama waktu pengasapan sebagai perlakuan dan lama waktu penyimpanan pada ikan tandipang. Berdasarkan hasil uji laboratorium kadar protein tertinggi $(53,15)$ terdapat pada perlakuan K1K2 (pengasapan dengan kayu kelapa dengan lama 30 menit dan disimpan selama 20 hari). Kadar protein terendah $(44,24)$ terdapat pada perlakuan A1B3 (pengasapan dengan sabut kelapa dengan lama 30 menit dan disimpan selama 30 hari), kadar air tertinggi $(20,2)$ terdapat pada perlakuan A1B2 (pengasapan dengan sabut kelapa selama 30 menit dan disimpan selama 20 hari) dan kadar air terendah $(15,85)$ terdapat pada perlakuan A1B1 (pengasapan dengan sabut kelapa selama 30 menit dan disimpan selama 10 hari), kandungan lemak tertinggi $(10,21)$ terdapat pada perlakuan A1B3 (pengasapan dengan sabut kelapa selama 30 menit dan disimpan selama 30 hari) dan kadar lemak terendah $(4,44)$ terdapat pada perlakuan A4B3 (pengasapan dengan sabut kelapa selama 2 jam dan disimpan selama 30 hari), kandungan karbohidrat tertinggi $(15,99)$ terdapat pada perlakuan A2B1 (pengasapan dengan sabut kelapa selama 45 menit dan disimpan selama 10 hari) dan kadar karbohidrat terendah $(9,39)$ terdapat pada perlakuan K1K2 (pengasapan dengan kayu kelapa selama 30 menit dan disimpan selama 20 hari), dan kadar abu tertinggi $(13,45)$ terdapat pada perlakuan A4B1 ( pengasapan dengan sabut kelapa selama 2 jam dan disimpan selama 10 hari) dan kadar abu terendah $(10,56)$ pada perlakuan A3B3 (pengasapan dengan sabut kelapa selama 60 menit dan disimpan selama 30 hari).
\end{abstract}

Kata kunci: ikan tandipang, pengasapan

Jurnal Frontiers Vol 1 No 3, Desember 2018 


\section{ABSTRACT}

The use of fish resources in Indonesia, especially traditionally, semi-traditional and modern marine catches, has been well developed. Traditional fish processing using the fogging or drying method is quite developed in Indonesia, especially in the North Sulawesi province. One of the dried smoked fish products that is quite famous in North Sulawesi, especially in South Minahasa Regency, namely tandipang fish. The purpose of this study was to measure the nutritional content of tandipang fish and measure the shelf life of tandipang fish. Quality is a combination of a number of attributes possessed by ingredients or food products that can be assessed organoleptically. Organoleptic value of smoked fish according to SNI No. 01-27251992 is $>7$ with attractive and clean appearance criteria, sufficient smoke odor without any additional disturbing, good taste, solid consistency, compact and dry between tissues (Nastiti, 2006). The research method used was a randomized block design with a variable length of fumigation time as a treatment and a long storage time in tandipang fish. Based on the results of laboratory tests the highest protein content (53.15) was found in the K1K2 treatment (fumigation with coconut wood with a duration of 30 minutes and stored for 20 days). The lowest protein content (44.24) was found in AlB3 treatment (fumigation with coconut fiber with 30 minutes long and stored for 30 days), the highest water content (20.2) was found in AlB2 treatment (fumigation with coconut fiber for 30 minutes and stored for 20 days) and the lowest water content (15.85) found in treatment A1B1 (fumigation with coconut fiber for 30 minutes and stored for 10 days), the highest fat content (10.21) found in treatment AlB3 (fumigation with coconut fiber during 30 minutes and stored for 30 days) and the lowest fat content (4.44) found in the treatment A4B3 (fumigation with coconut fiber for 2 hours and stored for 30 days), the highest carbohydrate content (15.99) is found in treatment A2BI (fumigation with coconut fiber for 45 minutes and stored for 10 days) and the lowest carbohydrate content (9.39) found in the K1K2 treatment (fumigation with coconut wood for 30 minutes and stored for 20 days), and the level of tertiary ash ggi (13.45) is found in the treatment A4B1 (fumigation with coconut fiber for 2 hours and stored for 10 days) and the lowest ash content (10.56) in the A3B3 treatment (fumigation with coconut fiber for 60 minutes and stored for 30 days.

Keywords: tandipang fish, fumigation

\section{PENDAHULUAN}

Pengolahan ikan tradisonal dengan menggunakan metode pengasapan atau pengeringan cukup berkembang di Indonesia, khususnya di daerah provinsi Sulawesi Utara. Swastawati, dkk.(2013) menyatakan bahwa kualitas ikan asap merupakan gambaran karakteristik dari produk tersebut yang mempengaruhi akseptabilitas konsumen. Pengasapan ikan sebagian besar masih bersifat tradisional, dan belum mempertimbangkan faktor kesehatan dan keamanan pangan. Di samping itu pengasapan tradisional seringkali memberikan dampak negatif terhadap lingkungan, serta menimbulkan kekhawatiran konsumen terhadap senyawa karsinogenik dan polusi udara, namun kenyataannya hasil produk tetap digemari oleh masyarakat.

Salah satu produk ikan asap kering yang cukup terkenal di wilayah Sulawesi Utara khususnya di Kabupaten Minahasa Selatan yakni ikan tandipang. Ikan tandipang yang diolah berdasarkan informasi dari responden sebagai pemilik usaha tandipang terdiri dari 2 jenis yakni jenis Dussumieria acuta (Valenciennes,1847) dalam bahasa perdagangan dikenal dengan nama raibow sardinedanjenis

Dussumieria elopsoides;Bleeker 1849)dalam bahasa perdagangan disebut sebagai slender rainbow sardine. Kaparang, dkk (2013) menyatakan bahwa ikan tandipang merupakan salah jenis ikan yang dihasilkan dari proses pengeringan yang 
dikombinasikan dengan pengasapan. Produk ini memberikan citarasa tersenderi yang lezat, gurih dengan aroma yang khas disebabkan adanya kombinasi proses pengeringan dan pengasapan.

Kajian tentang mutu ikan tandipang (Dussumieria acuta) dengan metode asap kering selama penyimpanan suhu kamar telah dilakukan oleh Kaparang, dkk (2013) dan sampai saat ini belum ada kajian dan dokumentasi ilmiah tentang kandungan nilai gizi dari ikan tandipangberdasarkan lama waktu pengasapan.Berdasarkan hal tersebut, maka perlu dilakukan penelitian tentang kandungan nilai gizi dari ikan tandipang berdasarkan lamanya waktu pengasapan.

\section{TINJAUAN PUSTAKA}

Mutu

Mutu adalah gabungan dari sejumlah atribut yang dimiliki oleh bahan atau produk pangan yang dapat dinilai secara organoleptik. Atribut tersebut meliputi parameter kenampakan, warna, tekstur,rasa dan bau (Kramer dan Twigg,1983). Menurut Hubeis (1994), mutu dianggap sebagai derajat penerimaan konsumen terhadap produk yang dikonsumsi berulang (seragam atau konsisten dalam standar dan spesifikasi), terutama sifat organoleptiknya. Mutu juga dapat dianggap sebagai kepuasan (akan kebutuhan dan harga) yang didapatkan konsumen dari integritas produk yang dihasilkan produsen.

\section{Komposisi Kimia Daging Ikan}

Pemanfaatan ikan telah dilakukan sejak lama. Konsumsi ikan dimulai dari pengolahan secara tradisional, hingga pengolahan dengan menggunakan alat-alat moderen. Tujuannya sama, yaitu untuk memenuhi kebutuhan nutrisi tubuh. Tiaptiap jenis ikan memiliki kadar kandungan nutrisi yang berbeda-beda. Berdasarkan uji laboratorium terhadap daging ikan, secara umum ikan memiliki komposisi kimia (Afrianto dan Liviawaty, 1989) sebagai berikut :

Tabel 1. Komposisi kandungan kimia daging ikan

Kandungan Prosentase (\%)

Air $\quad 60-84,0 \%$

Protein $18,0-30,0 \%$

Lemak $0,1-2,2 \%$

Karbohidrat $\quad 0,0-1,0 \%$

Vitamin dan mineral $\quad 0,0-2,35 \%$

\section{Pengasapan}

Pengasapan merupakan cara pengolahan atau pengawetan ikan dengan memanfaatkan kombinasi perlakuan pengeringan dan pemberian senyawa kimia alami dari hasil pembakaran bahan bakar alamiyang dihasilkan dari pembakaran kayu dalam bentuk asap (Afrianto dan Liviawati, 1991). Senyawa asap tersebut menempel pada ikan dan larut dalam lapisan air yang ada di permukaan tubuh ikan, sehingga terbentuk aroma dan rasa yang khas pada produk dan warnanya menjadi keemasan atau kecoklatan (Wibowo, 1996).

Prinsip pengolahan ikan dengan pengasapan adalah pengeringan. Proses pengeringan ini memanfaatkan panas hasil pembakaran hingga menyebabkan keluarnya air dari jaringan pengikat ikan (tendon) sehingga membantu penyerapan senyawa-senyawa dari asap lebih cepat. Senyawa-senyawa ini menempel pada air yang berada pada permukaan ikan (Adawyah, 2007).Beberapa faktor yang mempengaruhi hasil pengasapan selama proses pengasapan yakni volume dan mutu 
asap, suhu, kelembaban udara, serta kecepatan udara dan pembagian asap.

\section{Ikan Tandipang}

Bahan baku yang digunakan dalam pengolahan ikan asap kering tandipang terdiri dari2 spesies, Dussumieria acuta dan Dussumieria elopsoides.

Kandungan utama mineral berdasarkan nilai rata-rata dan standar eror analisis komposisi proximat dari ikan tandipang (Dussumieria acuta) (Palani et al., 2014) bertutur-turut yakni kelembaban $74,07+0,02$; protein $20,23+0,28$; lemak $6,83+0,34 ;$ kadar abu $1,22+0,09 ;$ karbohidrat $0.083+0,005$ dan nilai energi 150,72 .

\section{METODE PENELITIAN}

Metode penelitian yang digunakan adalah metode eksperimental yaitu mengadakan percobaan untuk melihat suatu hasil. Hasil yang didapat akan menegaskan bagaimana hubungan sebab akibat tersebut, dengan cara memberikan perlakuan tertentu pada beberapa kelompok eksperimental dan menyediakankontrol untuk perbandingan (Nazir, 1988). Menurut Kusriningrum (2008) percobaan dapat didefinisikan sebagai suatu tindakan yang dibatasi dengan nyata dan dapat dianalisis hasilnya. Rancangan percobaan yang digunakan yakni Rancangan Acak Kelompok (RAK) menggunakan ANOVA. Apabila terdapat perbedaan, dilanjutkan dengan uji berjarak Duncan dengan tingkat signifikansi 5\%. Variabel yang diamati adalah lama waktu pengasapan sebagai perlakuan dan lama waktu penyimpanan pada ikan tandipang sebagai kelompok. Model matematika sebagai berikut :

$Y i j=\mu-\alpha i+\beta j-\epsilon i j$
Keterangan :

$$
\begin{array}{ll}
\mathrm{i} & =1,2,3, \ldots \mathrm{t} \\
\mathrm{j} & =1,2,3, \ldots \mathrm{n}
\end{array}
$$

( $\mathrm{t}$ = banyaknya perlakuan, $\mathrm{n}=$ banyaknya ulangan)

$$
\begin{aligned}
\text { Yij }= & \text { nilai pengamatan pada perlakuan } \\
& \text { ke-i ulangan ke- } \mathrm{j} \\
\mu \quad & \text { nilai rerata sampel } \\
\alpha \mathrm{i} \quad= & \text { pengaruh perlakuan ke-i } \\
\beta \mathrm{j} \quad & \text { pengaruh acak (kesalahan } \\
& \begin{array}{l}
\text { percobaan) pada perlakuan ke- } \mathrm{i} \\
\\
\end{array} \\
= & \text { ulangan ke- } \mathrm{j} \\
\epsilon \mathrm{ij} \quad & \begin{array}{l}
\text { Pengaruh dari variabel lain } \\
\end{array}
\end{aligned}
$$

\section{HASIL PEMBAHASAN \\ Protein}

Berdasarkan hasil penelitian yang dilakukan, kadar protein tertinggi terdapat pada sampel yang menggunakan kayu kelapa sebagai bahan pengasapan dan diasap selama 10 menit serta disimpan selama 20 hari (K1K2). Kadar protein terendah terdapat pada sampel yang menggunakan sabut kelapa sebagai bahan pengasapan dan diasap selama 10 menit serta disimpan selama 30 hari (A1B3)

Menurut Sebranek (2009), tinggi atau rendahnya nilai protein yang terukur dapat dipengaruhi oleh besarnya kandungan air yang hilang (dehidrasi) dari bahan. Nilai protein yang terukur akan semakin besar jika jumlah air yang hilang semakin besar.

Nilai kadar protein pada ikan tandipan dapat dilihat pada grafik 1 .

\section{Lemak}

Hasil analisa kadar lemak menunjukkan bahwa kadar lemak tertinggi tterdapat pada ikan yang diasap selama 10 
menit dengan menggunakan sabut kelapa dan disimpan selama 30 hari (A1B3) dan kadar lemak terendah terdapat pada control yaitu ikan yang diasap selama 1 jam menggunakan sabut kelapa dan disimpan selama 30 hari (A4B3).

Swastawati (2014) menyatakan bahwa semakin tinggi suhu dan lama pengasapan menyebabkan menurunnya nilai kadar lemak, kadar air bahan menurun menyebabkan kandungan bahan padatan misalnya protein, lemak dan zatzat vitamin akan meningkat. Hadjinikolova (2008) menambahkan, proses pengolahan dengan menggunakan prinsip pemanasan seperti pengeringan, pengukusan dan pengasapan akan menyebabkan sebagian lemak meleleh keluar dari bagian-bagian daging ikan tetapi pengukuran kandungan lemak juga akan dipengaruhi oleh kandungan air yang terukur. Kadar lemak ikan tandipan dapat dilihat pada Grafik 2.

\section{Kadar Air}

Hasil analisa kadar air ikan tandipan adalah pada ikan yang diasap selama 20 menit menggunakan sabut kelapa dan disimpan selama 20 hari. Sedangkan kadar air terendah terdapat pada ikan yang diasap selama 10 menit menggunakan sabut kelapa dan disimpan selama 10 hari (A1B1).

Menurut Wibowo (2000) perubahan kadar air pada proses pengasapan diakibatkan karena panas dan penarikan air dari jaringan tubuh ikan oleh penyerapan berbagai senyawa kimia dari asap. Selanjutnya menurut Desroiser (1988) proses pengeringan didasari atas terjadinya penguapan (pengisapan) air oleh udara sebagai akibat perbedaan kandungan uap air antara udara dan produk yang dikeringkan. Grafik kadar air dapat dilihat pada grafik 3 .

\section{KADAR ABU}

Berdasarkan hasil analisa kadar abu yang dilakukan, kadar abu tertinggi pada ikan tandipang terdapat pada perlakuan ikan yang diasapi selama 10 menit menggunakan sabut kelapa dan disimpan selama 10 hari (A1B1). Sedangkan kadar abu terendah terdapat pada perlakuan ikan yang diasapi selama 1 jam menggunakan sabut kelapa dan disimpan selama 30 hari (A3B3).

Perbedaan kadar abu, disebabkan oleh lama waktu pengasapan serta jenis ikan yang digunakan. Menurut Kanoni (1991),kenaikan kadar abu terjadi karena pengendapan unsur0unsur yang terdapat dalam mineral adalah fosfor, kalsium, potassium, sodium, magnesium, belerang, dan klorin. Menurut Sudarmadji et al (2003), kadar abu berhubungan dengan mineral suatu bahan. Mineral yang terdapat dalam bahan dapat merupakan dua macam garam, yaitu garam organic dan anorganik. Untuk hasil uji kadar abu dapat dilihat pada Grafik 4.

\section{Karbohidrat}

Karbohidrat memegang peranan penting karena merupakan sumber energy utama bagi hewan dan manusia. Jumlah kalori yang dihasilkan oleh 1 gram karbohidrat adalah 4 kkal.

Berdasarkan hasil analisa, karbohidrat tertinggi terdapat pada perlakuan ikan yang diasapi selama 45 menit menggunakan sabut kelapa dan disimpan selama 10 hari (A2B1). Sedangkan karbohidrat terendah terdapat pada perlakuan ikan yang diasapi selama 10 menit menggunakan kayu kelapa dan disimpan selama 20 hari (K1K2). Menurut Winarno (2004), kandungan karbohidrat sangat dipengaruhi oleh factor kandungan gizi lainnya. Semakin tinggi kandungan protein, lemak, air, dan abu maka semakin rendah kadar 
karbohidratnya. Hasil uji karbohidrat dapat dilihat pada grafik 5 .

\section{Kandungan bakteri E. Coli}

Berdasarkan hasil analisa, kandungan bakteri E. Coli tertinggi terdapat pada perlakuan ikan yang diasap selama 1 jam menggunakan kayu kelapa dan disimpan selama 10 hari (kontrol K4K1).

Menurut Yahono, (2004), teknik pengasapan tradisional biasanya menggunakan peralatan yang sederhana, tanpa adanya pertimbangan untuk menjaga mutu ikan sebagai bahan pangan mentah dengan standar sanitasi dan higienis yang sangat rendah. Hal tersebut dapat menimbulkan kontaminasi pada produk akhir. Dan kontaminasi itu sendiri bias diakibatkan kebiasaan para pekerja yang tidak bersih. Hasil analisa uji E. coli dapat dilihat pada Grafik 6.

\section{PENUTUP \\ Kesimpulan}

1. Kandungan nilai gizi ikan tandipan sebagai berikut:

a. Protein : kadar protein tertinggi terdapat pada perlakuan K1K2 ( pengasapan dengan kayu kelapa dengan lama 30 menit dan disimpan selama 20 hari). Kadar protein terendah terdapat pada perlakuan A1B3 (pengasapan dengan sabut kelapa dengan lama 30 menit dan disimpan selama 30 hari)

b. Kadar air : kadar air tertinggi terdapat pada perlakuan A1B2 (pengasapan dengan sabut kelapa selama 30 menit dan disimpan selama 20 hari) dan kadar air terendah terdapat pada perlakuan A1B1 (pengasapan dengan sabut kelapa selama 30 menit dan disimpan selama 10 hari) c. Kadar abu tertinggi pada ikan tandipang terdapat pada perlakuan ikan yang diasapi selama 10 menit menggunakan sabut kelapa dan disimpan selama 10 hari (A1B1). Sedangkan kadar abu terendah terdapat pada perlakuan ikan yang diasapi selama 1 jam menggunakan sabut kelapa dan disimpan selama 30 hari (A3B3)

d. Kadar lemak tertinggi tterdapat pada ikan yang diasap selama 10 menit dengan menggunakan sabut kelapa dan disimpan selama 30 hari (A1B3) dan kadar lemak terendah terdapat pada control yaitu ikan yang diasap selama 1 jam menggunakan sabut kelapa dan disimpan selama 30 hari (A4B3).

e. Karbohidrat tertinggi terdapat pada perlakuan ikan yang diasapi selama 45 menit menggunakan sabut kelapa dan disimpan selama 10 hari (A2B1). Sedangkan karbohidrat terendah terdapat pada perlakuan ikan yang diasapi selama 10 menit menggunakan kayu kelapa dan disimpan selama 20 hari $(\mathrm{K} 1 \mathrm{~K} 2)$.

2. Kandungan E. coli tertinggi pada ikan tandipan terdapat pada perlakuan K4K1 (pengasapan dengan kayu kelapa selama 2 jam dan disimpan selama 10 hari) dan kandungan terendah adalah $2.7 \mathrm{APM} / \mathrm{gr}$

\section{Saran}

1. Perlu dilakukan uji pembanding agar didapatkan standart mutu ikan tandipang.

2. Perlu dilakukan uji organoleptik ikan tandipang. 
3. Perlu dilakukan uji masa simpan agar diketahui berapa lama masa simpan ikan tandipang.

\section{DAFTAR PUSTAKA}

Adawyah, R. 2007. Pengolahan dan Pengawetan Ikan. PT. Bumi Aksara.Jakarta. $159 \mathrm{hlm}$.

Afrianto, E dan E. Liviawaty. 1989. Pengawetan dan Pengolahan Ikan. Kanisius, Yogyakarta. $125 \mathrm{hlm}$.

Afrianto, E. 2008. Pengawasan Mutu Bahan/Produk Pangan. Direktorat Pembinaan Sekolah Menengah Kejuruan. Jakarta

Agus. T.S.W., F. Swastawati, da A.P. Anggo. 2014. Kualitas Ikan Pari (Dasyatis sp) Asap Yang Diolah Dengan Ketinggian Tunggu Dan Suhu Yang Berbeda. Jurnal Pengolahan dan Bioteknologi Hasil Perikanan,Vol 3. No.1 hal 147156. http://www.ejournalsl,undip.ac.id/index.php/jpbhp.

Diakses: 13 agustus2015

Appeltans, W. 2011.World Register of Marine Species. Worms. Retrieved 2/11/2011, Accessed from www.marinespecies.org. May, 03, 2016.

[AOAC] Association of Official Analytical Chemist. 2005. Official Method of Analysis of the Association of Official Analytical of Chemist. Arlington: The Association of Official Analytical Chemist, Inc.

Bailey, C., A. Dwiponggo \& F. Maharudin. 1987. Indonesia Marine Capture Fisheries. International Center for Living
Aquatic Resources Management, Philippines; Directorate General of Fisheries, Ministry of Agriculture, Indonesia; Marine Fisheries Research Institute, Ministry of Agriculture, Indonesia.ICLARM Constribution No. 388.p.3.

Bhuiyan, A.K.M.A., W.M.N Ratnayake, and R.G. Ackman. 1993. Nutritional composition of raw and smoked Atlantic mackerel (Scomber scombrus): oil and water solube vitamins. J. Food Composition and Analysis. 6: 172184.

Bligh, E.G., S.J. Shaw, and A.D. Woyewoda. 1998. Effects of drying and smoking on lipids of fish In Fish Smoking and Drying, the Effects of Smoking and Drying on the Nutritional Properties of Fish. J.R Burt, (Ed.). Elsevier Applied Science, London and New York. p. 41-45.

Budiman, A., Arief, A.J. \& A.H. Tjakrawidjaya. 2002. Peran museum zoologi dalam penelitian dan konservasi keanekaragaman hayati (ikan). Jumal Iktiologi Indonesia Vol.2, No. 2: 51-55.

Burt, J.R. 1988. The effect of drying and smoking on the vitamine content of fish In Fish Smoking and Drying, the Effects of Smoking and Drying on the Nutritional Properties of Fish. J.R Burt, (Ed.). Elsevier Applied Science, London and New York. p. 53-60.

Cahyo, S dan D. Hidayati. 2006. Bahan Tambahan Pangan. Kanisius. Yogyakarta. 
Doe, PE. 1998. Fish Drying and Smoking: Production and Quality.Pennsylvania.Technomic Publication.

Effendi S. 2012. Teknologi Pengolahan Pangan dan Pengawetan Pangan. Bandung (ID): Alfabeta

Eschmeyer andN. William. 1998. Catalog of Fishes. Special Publication of the Center for Biodiversity Research and Information.California Academy of Sciences.San Francisco, California, USA. No. 1. Vol 1-3. p 2905.

Fauzi dan A. Muchtar. 2011. Pengasapan Ikan Menggunakan Lemari Asap Skala Rumah Tangga. Jurnal Perikanan dan Kelautan.Vol. 16 No. 1: 103-116.

Froese, R., and D. Pauly. 2012. Fish Base: World wide web electronic publication. www.fishbase.org, version 02/2011. Penang, Malaysia, World Fish Center.

Green, J.H. and A. Kramer. 1979. Food Processing Waste management.AVI Westport, CT.

Hadjinikolova, L. 2008.Investigations on the Chemical Composition of Carp (Cyprinus carpioL), Bighead Carp(Aristichthys nobilis Rich) and Pike (Esox lusius L) during Different Stages of Individual Growth. Bulgarian Journal of Agricultural Science14: 121-126.

Heruwati, E.S. 2002. Pengolahan Ikan Secara Tradisional: Prospek dan Peluang Pengembangan. Jurnal Litbang Pertanian. 21(3):92-99.
Isamu K.T., H. Purnomodan S.S. Yuwono. 2012.Karakteristik Fisik, Kimia, Dan Organoleptik Ikan Cakalang (Katsuwonus Pelamis) Asap Di Kendari.Jurnal Teknologi Pertanian Vol. 13 No. 2: 105-110.

Kanoni, Sri. 1991. Kimia dan Teknologi Pengolahan Ikan. Pusat Antar Universitas Pangan dan Gizi. Universitas Gajah Mada. Yogyakarta.

Kaparang R., S.D. Harikedua dan I.K. Suwetja. 2013. Penentuan Mutu Ikan Tandipang (Dussumieria acuta C.V) Asap Kering Selama Penyimpanan Suhu Kamar. Jurnal Media Teknologi Hasil Perikanan. Vol.1, No.1:1-6.

Kusriningrum, R.S. 2008. Perancangan Percobaan. Airlangga University Press. Surabaya.

Moeljanto R. 1982. Pengolahan Hasil Sampingan Ikan. Penebar Swadaya. Jakarta. $33 \mathrm{hlm}$.

Murniyati, A.S. 2004.Biologi 100 ikan laut ekonomis penting di Indonesia.Departemen Kelautan dan Perikanan.Pusat Pendidikan dan Pelatihan Perikanan.Jakarta.

Murniyati, A.S dan Sunarman. 2000. Pendinginan, Pembekuan dan Pengawetan Ikan. Kanisius. Yogyakarta.

Nazir. 1988. Metode Penelitian. Penerbit Ghalia Indonesia. Jakarta.

Nastiti, D. 2006. Kajian Peningkatan Mutu Produk Ikan Manyung (Arius thalassinus) Panggang di Kota Semarang.TESIS. Program Studi 
Magister Manajemen Sumberdaya Pantai. Program Pascasarjana. Universitas Diponegoro. Semarang. Tidak Dipublikasikan.

Palani K.M, A.A Ruba, S.R Jeya andS.A Shanmugam. 2014. Proximate and Major Mineral Composition of 23 Medium SizedMarine Fin Fishes Landed in the Thoothukudi Coast of India. J Nutr Food Sci 4: 1-7.

Pan B.S. 1988. Undersirable factors in dried fish products In Fish Smoking and Drying, the Effects of Smoking and Drying on the Nutritional Properties of Fish. J.R Burt, (Ed.). Elsevier Applied Science, London and New York. p. 61-71.

Raghunath, M.R., T.V. Sankar, K. Ammu, and K. Devadasan. 1995. Biochemical and nutritional changes in fish protein during drying. J.Sci.Food Agric.67:197204.

Ravichandran S., F.R.S Joseph, R. Kanagalakshmi and M.S. Ramya, 2012. Variation in Nutritive Composition of Two Commercially Important Marine Fin Fishes.International Journal of Zoological Research.8: 43-51

Sebranek, J. 2009. Basic Curing Ingredients. Di dalam: Tarte $\mathrm{R}$, editor. Ingredients in Meat Product. Properties, Functionality and Applications. New York: Springer Science. hlm 1-24.

Sikorski, Z., N. Haard, T. Motohiro, and B.S. Pan. 1988. Quality In Fish Smoking and Drying, the Effects of Smoking and Drying on the Nutritional Properties of Fish. J.R
Burt, (Ed.). Elsevier Applied Science, London and New York. p. 89-115.

Sudarmaji, S. Haryono dan B. Suhardi. 1997. Prosedur Analisa untuk Bahan Makanan dan Pertanian. Liberty. Yogyakarta.

Sudarmadji, S., B. Hariyono., dan Suhardi, 2003. Analisa Bahan Makanan dan Pertanian. Liberty. Yogyakarta. $171 \mathrm{hlm}$.

Swastawati F,T. Surti,T.W. Agustini,P.H. Riyadi. 2013. Karakteristik Kualitas Ikan Asap Yang Diproses Menggunakan Metode dan Jenis Ikan Berbeda Jurnal Aplikasi Teknologi Pangan Vol.2 (3):126132.

SNI.2006.Pengujian Kadar Protein pada Produk

Perikanan.SNINo.01-2354.4.2006.

BadanStandarisasiNasional.

SNI.2006.Pengujian Kadar Abu pada Produk Perikanan.SNINo.012354.1.2006.BadanStandarisasi Nasional.

SNI.2006.Pengujian Kadar Air pada Produk Perikanan.SNINo.012354.2.2006.BadanStandarisasi

Nasional.

SNI.2006.Pengujian Kadar Lemak pada Produk Perikanan.SNINo.012354.3.2006.BadanStandarisasiNas ional.

Wibowo S. 2017. Industri Pengasapan Ikan. Jakarta (ID): PT Penebar Swadaya

Whitehead, P.J.P. 1985. FAO Species Catalogue.Vol. 7. Clupeoid fishes of the world (suborder 
D. H. Ndahawali, H. M. P. Ondang Jurnal Sains dan Teknologi, Universitas Negeri Manado

Clupeioidei). An annotated and illustrated catalogue of the herrings, sardines, pilchards, sprats, shads, anchovies and wolfherrings.FAO Fish.Synop. 125(7/1):1-303. Rome: FAO. p 12.

Winarno FG. 2004. Kimia Pangan dan Gizi. PT. Gramedia Pustaka Utama: Jakarta.

Yahono, S.B. 2004. Kajian Beberapa Aspek Pengolahan Ikan Secara Tradisional Dalam Upaya Peningkatan Mutu Produk Perikanan di Kabupaten Jepara. Tesis Manajemen Sumber Daya Pantai. Pasca Sarjana Universitas Diponegoro. Semarang 